\title{
Relationship between Motivation, Knowledge, and Availability with the Use of Personal Protective Equipment
}

\author{
Hubungan Motivasi, Pengetahuan, Ketersediaan Alat Pelindung Diri dengan \\ Penggunaan Alat Pelindung Diri
}

\author{
Yogi Adiputro \\ Clinical Laboratory of Kimia Farma \\ Jl. Raya Darmo No. 6 Tegalsari Surabaya, East Java, Indonesia, 60264
}

\begin{abstract}
Introduction: Clinical laboratories are a kind of workplace that must be designed in strict compliance with occupational health and safety standards to create a safe work environment. Fatal work accidents can inflict injuries caused by improper use of equipment, poisoning due to chemical substances in clinical laboratories, and transmission of dangerous diseases. Methods: This is an observational research with a cross sectional approach. The population of this study was 15 health analysts in the X Regional Clinical Laboratory of East Java. The research used total sampling method, carried out from July to September 2018. The dependent variable is the use of PPE and the independent variables are the lack of control and the basic causes. Data were analyzed using Chi square and Spearman correlation tests. Results: 53.3\% of the employees of X Regional Clinical Laboratory of East Java use PPE accordingly. There is a strong relationship between knowledge and the use of PPE ( $r=0.607)$. There is a strong correlation between the motivation and the use of PPE $(r=0.600)$. There is a strong relationship between the availability of PPE and the use of PPE $(r=0.756)$. Conclusion: There is a strong relationship between knowledge, motivation, and availability of PPE with the use of PPE.
\end{abstract}

Keywords: knowledge, motivation, personal protective equipment

\begin{abstract}
ABSTRAK
Pendahuluan: Laboratorium Klinik merupakan tempat kerja yang perlu dirancang sesuai dengan standar kesehatan dan keselamatan kerja untuk menciptakan lingkungan kerja yang aman. Kecelakaan kerja yang fatal dapat berakibat pada timbulnya luka yang diakibatkan karena penggunaan peralatan yang tidak tepat, keracunan akibat bahan kimia yang berada di laboratorium klinik dan penularan penyakit berbahaya. Metode: Penilitian ini bersifat observasional dengan pendekatan cross sectional. Populasi dalam penelitian ini adalah karyawan yang berjumlah 15 orang yang merupakan analis kesehatan di Laboratorium Klinik X Regional Jawa Timur. Teknik penentuan jumlah sampel menggunakan total sampling. Penelitian ini dilakukan pada JuliSeptember 2018. Variabel dependen penelitian adalah penggunaan APD, dan variabel independen adalah lack of control, dan basic causes. Data dalam penelitian ini dianalisis menggunakan uji korelasi chi square dan spearman. Hasil: Sebesar 53,3\% karyawan di Laboratorium Klinik X Regional Jawa Timur menggunakan APD dengan sesuai. Terdapat hubungan yang kuat antara pengetahuan dengan penggunaan APD $(r=0,607)$. Terdapat hubungan yang kuat antara motivasi dengan penggunaan APD $(r=0,600)$. Terdapat hubungan yang kuat antara ketersediaan APD dengan penggunaan APD ( $r=0,756)$. Simpulan: Terdapat hubungan yang kuat antara pengetahuan, motivasi dan ketersediaan APD dengan penggunaan APD.
\end{abstract}

Kata kunci: alat pelindung diri, motivasi, pengetahuan

Author for Correspondence:

Yogi Adiputro

Email: yogiadiputro@gmail.com

Phone: +6281805008765 


\section{INTRODUCTIONS}

Clinical Laboratory is a support facility for determining information about individual health. It is a health clinic laboratory that conducts research of clinical specimens to obtain information about individual health, in particular to support efforts to diagnose diseases, cure diseases, and restore health. Minister of Health the Republic Indonesia (2010)

To fulfill those objectives, clinical laboratories require various equipment that may pose risks for users, be it physical, chemical, ergonomic and biological, as well as psychosocial (Gunawan and Mudayana, 2016). Therefore, it is necessary to control the risk factors to guarantee the health and safety of the users in clinical laboratories.

Clinical laboratories are a type of workplace that needs to be designed in compliance with health and safety standards to create a safe working environment to prevent accidents at work that can harm both employees and the company. Fatal occupational accidents can cause injury due to the improper use of equipment, chemical poisoning by dangerous substances, and transmission of dangerous diseases resulting from contact with body fluids tested in the laboratories.

Medical staff is a profession with a potential risk of getting infected by patients' viruses. The number of incidence in which health workers get infected with hepatitis B or HIV/AIDS is high, thus highlighting the need of general awareness to such problem. Infection can be transmitted through open wounds caused by needles, scalpels, or other sharp objects. In addition, transmission can also be a result of exposure of mucous membranes to the patients' body fluids. High-risk groups of hepatitis B infection include doctors, surgeons, dentists, nurses, midwives, operating room officers, and laboratory officers. All of whom have daily contact with patients and human material such as blood, feces, and urine (Madyanti, 2012).

According to previous data, it can be seen that the risk of laboratory employees originates from accidents at work that cause injuries due to laboratory equipment usage, and transmission of diseases. According to Suma'mur (1996), accidents in workplace are accidents happened in the workplace and associated with labor relations with the companies. Work relationships here may refer to an accident caused by work or happened when a job is being carried out.

According to Ramli (2010), work-related accident is influenced by two direct causes: unsafe actions and unsafe conditions. Unsafe action is an action that does not comply with safety standards, creating a risk of accidents at work. A study conducted by Heinrich in 1928 shows that from up to a maximum of 75,000 cases of industrial accidents, $88 \%$ were caused by unsafe actions, $10 \%$ were caused by unsafe conditions, and $2 \%$ of them were unavoidable. Furthermore, unsafe action is considered as human factor, which includes, but not limited to, an individual doing a job without the proper use of Personal Protective Equipment (PPE).

PPE plays an important role in health and safety at work. According to the Regulation of the Minister of Manpower and Transmigration of the Republic of Indonesia (2010) personal protective equipment is a protective tool which function is to isolate part or all of the body from potential hazards in the workplace. President of the Republic of Indonesia (1970), Article 12 (1) (b): Legislation regulates the obligation and/or rights of employees to use personal protective equipment. Minister of Manpower and Transmigration of the Republic of Indonesia (1981) Article 4 (3) mentions the obligation of management to offer personal protective equipment, and that it is mandatory for employees to use it to prevent occupational diseases. Regulation of the Minister of Labour and Transmigration of the Republic of Indonesia (2010), Article 4 (1) states that PPE must be used in the workplace. Article 5 states that entrepreneurs or managers must inform and publicize in writing the obligation to use personal protective equipment in the workplace.

Regulating the proper use of PPE is an effort to prevent work accidents. This is supported by Harlan and Paskarini (2014) who state that the majority $(60 \%)$ of the laboratory personnel in PHC Surabaya Hospital showed deficient behavior in the use of PPE. Study by Janah (2009) shows that up to $66.7 \%$ of the clinical pathology laboratory officers at the Sidoarjo Hospital did not always wear PPE when they performed their work activities. Rahayu (2011) states that $33.7 \%$ of the officers of the laboratory service unit in the city of Bandar Lampung did not use PPE at work.

Based on the data above, it can be seen that the use of PPE by laboratory staff still needs to be improved. This requires attention 
since there is a high risk of diseases being transferred to laboratory staff. Moreover, losses resulted from laboratory staffs who get contracted are very high. In addition, the effects of disease transmission are very detrimental to the officers and companies where HIV and hepatitis have not been treated so far, while TB disease requires treatment of at least 6 months. This is very harmful to employees and also to the company because the infection decreases productivity and also leads to stigmatization and discrimination at work and in society (International Labour Organization and World Health Organization, 2005).

Occupational accidents resulting from the improper use or no use of PPE cause individuals to experience obstacles and disabilities, and even death. The financial consequences of these accidents will be very expensive. This is in line with what Wijayanto (2015) said, "Accident is expensive". He explains that the consequences of accidents at workplace are very expensive. Although everyone agrees that the use of PPE is very important, many employees show inconsistencies in using the PPE. That is why the researcher wants to investigate factors related to the use of PPE among employees of $\mathrm{X}$ Regional Clinical Laboratory of East Java.

\section{METHODS}

This is an observational research with cross-sectional approach. The population in this study consists of 15 health analysts employed by X Regional Clinical Laboratory of East Java. Sampling was performed using total sampling technique. This study was conducted from July to September 2018. The dependent variable of this study was the use of PPE. The independent variables were the lack of control and root causes. The data in this study were analyzed using chi square and spearman correlation testing.

\section{RESULT}

\section{Characteristics of Respondents}

Based on Table 1, all respondents (100\%) confirmed that there was a policy regarding the use of PPE (100\%).
Table 1. Distribution of the Policy Regarding PPE in X Regional Clinical Laboratory of East Java in 2018

\begin{tabular}{ccc}
\hline $\begin{array}{c}\text { Policy regarding } \\
\text { PPE }\end{array}$ & $\begin{array}{c}\text { Frequency } \\
(\mathbf{n})\end{array}$ & $\begin{array}{c}\text { Percentage } \\
(\boldsymbol{\%})\end{array}$ \\
\hline Exist & 15 & 100 \\
Not exist & 0 & 0 \\
\hline Total & 15 & 100 \\
\hline
\end{tabular}

Table 2. Distribution of Employees based on Knowledge at X Regional Clinical Laboratory of East Java 2018

\begin{tabular}{ccc}
\hline Knowledge & $\begin{array}{c}\text { Frequency } \\
(\mathbf{n})\end{array}$ & $\begin{array}{c}\text { Percentage } \\
(\boldsymbol{\%})\end{array}$ \\
\hline Good & 7 & 46.7 \\
Sufficient & 8 & 53.3 \\
Less & 0 & 0 \\
\hline Total & 15 & 100 \\
\hline
\end{tabular}

According to Table 3, it can be seen that the majority (60\%) of employees of X Regional Clinical Laboratory of East Java were highly motivated.

Table 3. Distribution of Employees based on Motivation at X Regional Clinical Laboratory of East Java in 2018

\begin{tabular}{ccc}
\hline Motivation & $\begin{array}{c}\text { Frequency } \\
(\mathbf{n})\end{array}$ & $\begin{array}{c}\text { Percentage } \\
(\boldsymbol{\%})\end{array}$ \\
\hline High & 9 & 60 \\
Moderate & 6 & 40 \\
Low & 0 & 0 \\
\hline Total & 15 & 100 \\
\hline
\end{tabular}

Table 4. Distribution of Employees based on Age at $X$ Regional Clinical Laboratory of East Java in 2018

\begin{tabular}{ccc}
\hline Age (Year) & Frequency (n) & Percentage (\%) \\
\hline $17-25$ & 7 & 46.7 \\
$26-35$ & 5 & 33.3 \\
$36-45$ & 2 & 13.3 \\
$46-55$ & 1 & 6.7 \\
\hline Total & 15 & 100 \\
\hline
\end{tabular}

Table 4 shows that the majority $(46.7 \%)$ of the workforce is in the age group of 17 to 25 years.

According to Table 5, it is known that the majority of employees working in the $\mathrm{X}$ Clinical Laboratory in the East of Regional Java have 3 years of work, which is equivalent to 11 respondents $(73.3 \%)$. 
Table 5. Distribution of Employees based on Term of Service at $X$ Regional Clinical Laboratory of East Java in 2018

\begin{tabular}{ccc}
\hline $\begin{array}{c}\text { Term of } \\
\text { Service (Year) }\end{array}$ & $\begin{array}{c}\text { Frequency } \\
(\mathbf{n})\end{array}$ & Percentage (\%) \\
\hline$\leq 3$ & 11 & 73.3 \\
$>3$ & 4 & 26.7 \\
\hline Total & 15 & 100 \\
\hline
\end{tabular}

Table 6. Distribution of Employees based on Education Levels at $\mathrm{X}$ Regional Clinical Laboratory of East Java in 2018

\begin{tabular}{ccc}
\hline Education Level & $\begin{array}{c}\text { Frequency } \\
(\mathbf{n})\end{array}$ & $\begin{array}{c}\text { Percentage } \\
(\boldsymbol{\%})\end{array}$ \\
\hline High school & 0 & 0 \\
Diploma & 15 & 100 \\
Bachelor & 0 & 0 \\
\hline Total & 15 & 100 \\
\hline
\end{tabular}

According to Table 6, it can be seen that all the respondents who work at X Regional Clinical Laboratory of East Java graduated from diploma programs.

Table 7. Distribution of Employees Opinion on the Availability of PPE at X Regional Clinical Laboratory of East Java in 2018

\begin{tabular}{ccc}
\hline Availability of PPE & $\begin{array}{c}\text { Frequency } \\
(\mathbf{n})\end{array}$ & $\begin{array}{c}\text { Percentage } \\
(\boldsymbol{\%})\end{array}$ \\
\hline Complete & 10 & 66.7 \\
Incomplete & 5 & 33.3 \\
\hline Total & 15 & 100 \\
\hline
\end{tabular}

According to Table 7, most employees (66.7\%) agreed that PPE is completely available at X Regional Clinical Laboratory of East Java in 2018.

According to Table 8, it can be seen that most employees (53.3\%) of X Regional Clinical Laboratory of East Java use PPE accordingly.

Table 8. Distribution of the use of PPE by Employees at $\mathrm{X}$ Regional Clinical Laboratory of East Java in 2018

\begin{tabular}{ccc}
\hline Use of PPE & $\begin{array}{c}\text { Frequency } \\
(\mathbf{n})\end{array}$ & $\begin{array}{c}\text { Percentage } \\
(\boldsymbol{\%})\end{array}$ \\
\hline Appropriate & 8 & 53.3 \\
Not appropriate & 7 & 46.7 \\
\hline Total & 15 & 100 \\
\hline
\end{tabular}

\section{Relationship between Knowledge of PPE and the Use of PPE}

Table 9. Cross Tabulation of Knowledge and Use of PPE among Employees of X Regional Clinical Laboratory of East Java of 2018

\begin{tabular}{|c|c|c|c|c|c|c|c|}
\hline \multirow{3}{*}{$\begin{array}{c}\text { Knowle } \\
\text { dge }\end{array}$} & \multicolumn{4}{|c|}{ Use of PPE } & \multirow{2}{*}{\multicolumn{2}{|c|}{ Total }} & \multirow{3}{*}{$\begin{array}{c}\text { Associa } \\
\text { tion } \\
\text { Coeffic } \\
\text { ient } \\
\text { Value }\end{array}$} \\
\hline & \multicolumn{2}{|c|}{$\begin{array}{c}\text { Appropri } \\
\text { ate }\end{array}$} & \multicolumn{2}{|c|}{$\begin{array}{c}\text { Inappro } \\
\text { priate }\end{array}$} & & & \\
\hline & n & $\%$ & n & $\%$ & $\mathbf{N}$ & $\%$ & \\
\hline Good & 6 & 40 & 1 & 6.7 & 7 & 46.7 & \multirow{4}{*}{0.607} \\
\hline $\begin{array}{c}\text { Sufficie } \\
\text { nt }\end{array}$ & 2 & 13.3 & 6 & 40 & 8 & 53.3 & \\
\hline Less & 0 & 0 & 0 & 0 & 0 & 0 & \\
\hline Total & 8 & 53.3 & 7 & 46.7 & 15 & 100 & \\
\hline
\end{tabular}

Referring to Table 9, it can be seen that the largest percentage of laboratory employees (40\%) who use PPE appropriately are those who also have good knowledge. Inappropriate use of PPE, respectively, are associated with employees with sufficient knowledge, which also comprises $40 \%$. The statistical test result shows an association coefficient value of 0.607 , which means that knowledge has a strong relationship with the use of PPE among the employees of X Regional Clinical Laboratory of East Java.

\section{Relationship between Motivation and the Use of PPE}

Table 10. Cross Tabulation of Motivation and Use of PPE among Employees of $\mathrm{X}$ Regional Clinical Laboratory of East Java in 2018

\begin{tabular}{|c|c|c|c|c|c|c|c|}
\hline \multirow{3}{*}{ Motivation } & \multicolumn{4}{|c|}{ Use of PPE } & \multirow[b]{2}{*}{ Total } & \multirow{2}{*}{\multicolumn{2}{|c|}{$\begin{array}{c}\text { Associat } \\
\text { ion } \\
\text { Coeffici } \\
\text { ent } \\
\text { Value } \\
\end{array}$}} \\
\hline & \multicolumn{2}{|c|}{$\begin{array}{c}\text { Appro } \\
\text { priate }\end{array}$} & \multicolumn{2}{|c|}{$\begin{array}{l}\text { Inapprop } \\
\text { riate }\end{array}$} & & & \\
\hline & n & $\%$ & $\mathbf{n}$ & $\%$ & $\mathbf{N}$ & $\%$ & \\
\hline High & 7 & 46.7 & 2 & 13.3 & 9 & 60 & \\
\hline Moderate & 1 & 6.7 & 5 & 33.3 & 6 & 40 & \\
\hline Low & 0 & 0 & 0 & 0 & 0 & 0 & 0.000 \\
\hline Total & 8 & 53.4 & 7 & 46.6 & 15 & 100 & \\
\hline
\end{tabular}

Table 10 highlights that the largest percentage of laboratory employees who use PPE appropriately is comprised of highly motivated ones ( 7 respondents, or $46.7 \%$ ). The inappropriate use of PPE, on the other hand, is mainly done by employees with moderate motivation (5 respondents, or $33.3 \%$ ). The 
statistical test result shows an association coefficient value of 0.600 , which means that motivation has a strong relationship with the use of PPE among the employees of X Regional Clinical Laboratory of East Java.

\section{Relationship between Availability of PPE and the Use of PPE}

Table 11. Cross Tabulation of PPE Availability and the Use of PPE among Employees of $\mathrm{X}$ Regional Clinical Laboratory of East Java in 2018

\begin{tabular}{|c|c|c|c|c|c|c|c|}
\hline \multirow{3}{*}{$\begin{array}{c}\text { Availabil } \\
\text { ity of } \\
\text { PPE }\end{array}$} & \multicolumn{4}{|c|}{ Use of PPE } & & \multirow[b]{2}{*}{ tal } & \multirow{2}{*}{$\begin{array}{c}\text { Associ } \\
\text { ation } \\
\text { Coeffic } \\
\text { ient } \\
\text { Value } \\
\end{array}$} \\
\hline & \multicolumn{2}{|c|}{$\begin{array}{l}\text { Approp } \\
\text { riate }\end{array}$} & \multicolumn{2}{|c|}{$\begin{array}{l}\text { Inapprop } \\
\text { riate }\end{array}$} & & & \\
\hline & $\mathbf{n}$ & $\%$ & n & $\%$ & $\mathbf{N}$ & $\%$ & \multirow{4}{*}{0.756} \\
\hline Complete & 8 & 53.3 & 2 & 13.4 & 10 & 66.7 & \\
\hline Incomplete & 0 & 0 & 5 & 33,3 & 5 & 33.3 & \\
\hline Total & 8 & 53.3 & 7 & 46.7 & 15 & 100 & \\
\hline
\end{tabular}

Referring to Table 11, it can be seen that the largest percentage of laboratory employees who use PPE appropriately are based on completely of availability of PPE (53.3\%). Statistical test result shows that availability of PPE does have a significant relationship with the use of PPE among the employees of X Regional Clinical Laboratory of East Java.

\section{DISCUSSION}

In ILCI theory, loss begins with a lack of control or a lack of management overseeing capability. In this study, lack of control can be associated with the laboratory's policy regarding the use of PPE by its employees.

Policy regarding PPE in this study falls under two categories: existent and non-existent. Existent means that the respondents mention that there are written rules made by companies regarding the requirement of PPE use at work. In the contrary, if according to the respondents there is no written rules regarding the use of PPE, it is categorized as non-existent.

Based on the results of the study, it is found that all respondents $(100 \%)$ were related to PPE in X Regional Clinical Laboratory of East Java. It shows that there are written regulations made by the company requiring the use of PPE at work.
Although the policy does exist and available in written form, it was not disseminated to all employees, so not all employees were aware of this policy. This is not in accordance with the opinion of Suma'mur (1996) stating that the companies must establish rules on the application of health and safety procedures at work, and that all parts of the companies must be aware of them. Knowledge is the result of knowing, and occurs after someone has experienced a certain object. Knowledge or cognitive is a domain that is very important to shape one's actions (manifest behavior). Knowledge is the result of observations and individual experiences of new things that can be useful for these people (Notoatmodjo, 2003).

The largest percentage of laboratory employees (40\%) who use PPE appropriately are those who also have good knowledge. Inappropriate use of PPE, respectively, are associated with employees with sufficient knowledge, which also comprises $40 \%$. The statistical test result shows an association coefficient value of 0.607 , which means that knowledge has a strong relationship with the use of PPE among the employees of X Regional Clinical Laboratory of East Java.

This result is in line with the research conducted by Gunawan and Mudayana (2016) on workers of production parts of PT Katingan Indah Utama, which states that there is a relationship between knowledge and behavior of using PPE. Gunawan and Mudayana's study also establishes that respondents with poor knowledge were 1,889 times more likely to have a behavior of improper use of PPE compared to the respondents with good knowledge.

However, this study is not in line with research conducted by Alhayati, Restuastuti and Fatmawati (2014) which states that there is no significant relationship between knowledge and the use of PPE in the laboratory of PK Arifin Achmad Hospital.

According to Notoatmodjo (2012) motivation is something that causes and supports the actions or behavior of a person. Based on the research findings, the largest percentage of laboratory employees who use PPE appropriately is comprised of highly motivated ones. The statistical test result shows an association coefficient value of 0.600 , which means that motivation has a strong relationship with the use of PPE. This shows that employees 
with high motivation will carry out safe behavior of properly using PPE.

This is consistent with the opinion of Deming and Covey cited in Geller (2001) the motivation of an individual is a form of principle that is embedded in oneself and that will affect all actions taken, including security. An individual will stick to the principle and will address each work routine that he or she performs, so a naturally safe behavior will be formed (Geller, 2001). A motivated workforce will have the will to behave safely. Motivation can make workers more careful in performing actions that affect their safety (Neal and Griffin, 2004).

The results of this study are in accordance with the research conducted by Hayulita and Paija (2014) on nurses in RSI Ibnu Sina Bukittinggi inpatient room. Hayulita states that there is a significant relationship between motivation and the use of PPE. In her research, it is stated that the greater the motivation given to nurses, the more often they use PPE. The results are also in line with those of Wijayanto (2015) that there is a relationship between nurses and patients receiving chemotherapy.

The occupational factor examined in this study is the availability of PPE. The availability of PPE has been regulated in Regulation of the Minister of Labour and Transmigration of the Republic of Indonesia (2010) that regulates the availability of PPE in the workplace. Even though every employer or company must provide PPE to workers in the workplace, the PPE must be adapted to the applicable standards and provided free of charge.

The results of the study show that most of the appropriate use of PPE occurs when the PPE is available. In the contrary, inappropriate use of PPE is due to unavailability. Results of the statistical tests show that the value of the association coefficient is 0.756 , which means that the availability of PPE has a strong relationship with the use of PPE. This means that the availability of PPE can affect the use of PPE among laboratory employees during works. If PPE is completely available, it may drive employees to use PPE accordingly.

The results of this study are in line with the research conducted by Liambo, Yasnani and Munandar (2017) in PLN technicians in the city of Kendari. They state that there was a relationship between the availability of PPE and the behavior of using PPE. Their study indicates that the availability of PPE facilities may be related to the behavior of using PPE because most of the availability of PPE in sufficient categories allows workers to use PPE completely in the workplace.

However, the results of this study are not in line with research conducted by Sari (2012) which states that there is no significant relationship between the availability of PPE and the behavior of using PPE.

\section{CONCLUSION}

Most employees of the $\mathrm{X}$ Regional Clinical Laboratory of East Java used PPE accordingly. There is a strong relationship between knowledge and the use of PPE. There is a strong relationship between motivation and the use of PPE. There is a strong relationship between the availability of PPE and the use of PPE.

\section{ACKNOWLEDGEMENT}

The researcher would like to thank all the respondents for their participation in the research.

\section{REFERENCES}

Alhayati, D. F., Restuastuti, T. and Fatmawati (2014) 'The Correlation between Clinical Pathology Laboratory Officers' Knowledges and Attitudes in Personal Protective Equipment Utilization in RSUD Arifin Achmad Riau Province', Jurnal Online Mahasiswa (JOM) Fakultas Kedokteran, 1(2), pp. 1-11.

Geller, E. S. (2001) The Pshychology Of Safety Handbook. United State America: Lewis Publishers.

Gunawan, I. and Mudayana, A. A. (2016) 'Relationship Between Knowledge, Attitudes and Motivation with Behavior of Use of Personal Protective Equipment in Production Workers PT Katingan Indah Kusuma, Kotawaringin Timur Regency, Central Kalimantan Province', Unnes Journal of Public Health, 5(4), pp. 336-347.

Harlan, A. N. and Paskarini, I. (2014) 'Factors Related to the Behavior of the Use of PPE in Laboratory Workers at PHC Surabaya Hospital', The Indonesian Journal of Occupational Safety, Health and Environment, 1(1), pp. 107-119. 
Hayulita, S. and Paija, F. (2014) 'The Correlation between Clinical Pathology Laboratory Officers' Knowledges and Attitudes in Personal Protective Equipment Utilization in RSUD Arifin Achmad Riau Province', Jurnal Ilmu Kesehatan 'Afiyah, 2(1), pp. 28-35.

International Labour Organization and World Health Organization (2005) Joint ILO / WHO Guidelines on Health Services and HIV / AIDS. Geneva: International Labour Organization and World Health Organization.

Janah, N. (2009) Several Factors Associated with the Use of Personal Protective Equipment at Workers of the Clinical Pathology Laboratory at Sidoarjo Hospital. Undergraduate Thesis. Surabaya: Faculty of Publich Health Universitas Airlangga.

Liambo, I. S. D., Yasnani and Munandar, S. (2017) 'Factors Associated with the Behavior of Use of Personal Protective Equipment (PPE) in PT PLN (Persero) Technician Area Sulselrabar Generation Sector Kendari Unit PLTD Wua-Wua Kendari City Year 2017', Jurnal Ilmiah Mahasiswa Keseahatan Masyarakat, 2(6), pp. 1-9.

Madyanti, D. R. (2012) Factors that Influence the Use of Personal Protective Equipment (PPE) in Midwives when Performing Labor Assistance in Bengkilis Hospital in 2012. Undergraduate Thesis. Depok: Faculty of Publich Health Universitas Indonesia.

Minister of Health the Republic Indonesia (2010) Number 411/MENKES/PER/ III/2010. Concerning Clinical Laboratories. Jakarta: Ministry of Health the Republic Indonesia.

Minister of Manpower and Transmigration of the Republic of Indonesia (1981) Obligations to Report Diseases Due to Work. Jakarta: Ministry of Manpower and Transmigration of the Republic of Indonesia.

Neal, A. and Griffin, M. A. (2004) 'Safety
Climate and Safety at Work', in Barling, J. and Frone, M. R. (eds) Psychology of Workplace Saftey. Washington, DC: American Phychological Association, pp. 15-34.

Notoatmodjo, S. (2003) Health Education and Behavior. Jakarta: PT. Rineka Cipta.

Notoatmodjo, S. (2012) Health Promotion and Health Behavior. Jakarta: Rineka Cipta.

President of the Republic of Indonesia (1970) Law Number 1 of 1970 about Occupational Safety. Jakarta: President of the Republic of Indonesia.

Rahayu, P. (2011) 'Factor Analysis of Use of Personal Protection Equipment (PPE) on Officers in the Laboratory Service Unit', Jurnal Kesehatan, 2(2), pp. 371-378.

Ramli, S. (2010) Occupational Health and Safety Management System (OHSAS 18001), K3 Management Series. Jakarta: Dian Rakyat.

Regulation of the Minister of Manpower and Transmigration of the Republic of Indonesia (2010) Number PER.08/MEN/VII/ 2010. Concerning Personal Protective Equipment, Jakarta: Minister of Manpower and Transmigration of the Republic of Indonesia. Jakarta: Ministry of Manpower and Transmigration of the Republic of Indonesia.

Sari, C. R. (2012) Characteristic Relationships Workers with Work Accidents. Undergraduate Thesis. Surabaya: Faculty of Public Health Universitas Airlangga.

Suma'mur, P. K. (1996) Corporate Hygiene and Occupational Health. Jakarta: PT. Toko Gunung Agung.

Wijayanto, W. (2015) Correlation between Nurses' Motivation and Their Attitude in the Use of Personal Protective Equipment at the Time of Chemotherapy Administration at the Inpatient Unit of Dr. Moewardi General Hospital of Surakarta Abstract. Undergraduate Thesis. Surakarta: Bachelor Degree Program in Nursing Science, STIKES Kusuma Husada. 